\title{
HUMAN RIGHTS IN SOUTH ASIA: ABUSE AND DEGRADATION*
}

\author{
Annapurna Waughray**
}

\section{INTRODUCTION}

This article is an expanded version of a paper $^{1}$ presented at a symposium held in March 2003 at Manchester Metropolitan University, Manchester, England. The purpose of the symposium was to examine, within the global context, the current situation regarding human rights in South Asia, to identify the obstacles to the full realization of human rights in the sub-continent, and to consider how those obstacles might be overcome. Four substantive papers ${ }^{2}$ were presented, focusing on specific human rights issues in South Asia, the themes of which were explored and developed in small workshops. This article presents a detailed overview of the issues discussed in the symposium and in particular the areas addressed in three of the substantive papers. ${ }^{3}$

Two observations in a recent Indian publication on human rights address directly the reality of human rights in South Asia today: firstly, that "no progress will ever make human rights superfluous or out of date, so long as humans face poverty and cruelty"; secondly, that "upholding human rights is to reverse the tendency to eliminate people because they are different, as no one has the right to say that everybody

\footnotetext{
* This article bears the title of the symposium organized at Manchester Metropolitan University in March 2003 by Burjor Avari, Senior Lecturer in Indian and South Asian History, Department of History and Economic History, and Coordinator for Multicultural Studies, Manchester Metropolitan University.

** Senior Lecturer in Law, School of Law, Manchester Metropolitan University.

1 A. Waughray, "Abuse and degradation: human rights in South Asia", unpublished, 2003.

2 D.A. Ghanchi, "Human rights in a fractured society: frustrations and fulfilment of the Indian experiment", unpublished, 2003; N. Malik, "The treatment of religious communities in Pakistan: the erosion of Jinnah's Vision", unpublished, 2003; J. Rehman, "South Asian Association for Regional Cooperation (SAARC): constitutionalism, regional peace and human rights", unpublished, 2003; U. Baxi, "Globalisation and human rights: winners and losers", taken from U. Baxi, People's Report on Human Rights Education: Introduction, revised final text, 2002.

3 Ibid., Ghanchi, Malik and Rehman.
}

Asian Yearbook of International Law, Volume 10 (B.S. Chimni et al., eds.)

(C) 2005 Koninklijke Brill NV. Printed in The Netherlands, pp. 25-56. 
should be like himself [sic]." ${ }^{4}$ These comments should not be considered as applicable only to the Indian experience. The reality of human rights across South Asia today is that millions face poverty and cruelty on a daily basis, whilst the tendency in the region to seek to eliminate 'the other' on grounds of religion, gender, caste, ethnicity, or nationality appears undiminished.

Constitutional and legislative protection of human rights is far from lacking in the region as a whole. Nevertheless, the South Asian experience illustrates the fact that "commitment on paper to human rights does not of itself change the reality on the ground". If "failure to act is caused by not just lack of knowledge, but also a kind of immunity to realities", ${ }^{6}$ the reality in the region, as evidenced by the speakers at the Manchester symposium, is that human rights violations are in large part due to a reluctance or inability to act in the face of realities, and in smaller but significant part to the wilful negation of human rights by the State and its agents, and by non-State actors - private individuals, organizations and corporations - from whose behaviour the State, under international human rights law and national legislation, has a duty to protect its citizens.

Section 2 of this paper presents an overview of the development and application of international human rights law and highlights those factors which continue to impede the full realization of human rights in South Asia. Section 3 considers the extent to which human rights and fundamental freedoms, particularly the rights of vulnerable groups and minorities, are respected in the context of South Asia. Sections 3.1 and 3.2 are based on the symposium paper by D.A. Ghanchi on the frustrations and fulfilments of the Indian experiment, and on Nadeem Malik's case study of the treatment of Ahmadi Muslims in Pakistan. Section 3.3 considers the issue of castebased discrimination. The discussion in the first part of Section 4 is extracted from the symposium paper presented by Javaid Rehman and considers the role, both current and potential, of the South Asian Association for Regional Cooperation (SAARC) as a force for peace, security, development, and the protection of human rights. There follows an examination of the role and potential of existing fora for the promotion and protection of human rights in South Asia in working towards the establishment of a sub-regional human rights system for South Asia. Section 5 offers some concluding thoughts. It is hoped that the preliminary observations in this article will contribute towards the stimulation of further debate on human rights and the rule of law, the treatment of women and religious minorities, the issue of caste discrimination, and the possibilities for greater regional cooperation in South Asia on human rights issues.

${ }^{4}$ C.J. Nirmal (ed.), Human Rights in India (New Delhi: OUP India, 2000), at xxvii-xxviii.

5 Ibid., at xxvii.

6 Ibid. 


\section{INTERNATIONAL HUMAN RIGHTS LAW AND SOUTH ASIA}

The 1993 Vienna Declaration and Programme of Action on Human Rights ${ }^{7}$ provides a useful starting point for our discussion. Unanimously endorsed by the one hundred and seventy-one states (including India, Pakistan, Bangladesh, Sri Lanka, Nepal, and Myanmar) represented at the UN-sponsored World Conference on Human Rights in Vienna in June 1993, the Declaration and Programme of Action categorically affirms that all human rights derive from the dignity and worth inherent in the human person, ${ }^{8}$ and that human rights and fundamental freedoms are the birthright of all human beings. ${ }^{9}$ According to Article 1 of the Vienna Declaration, the universal nature of the rights and freedoms expressed in the Charter of the United Nations, human rights instruments and international law is beyond question. ${ }^{10}$ At Article 5 the Vienna Declaration affirms that all human rights are universal, indivisible, interdependent, and interrelated; there can be no hierarchy or ranking of rights and no prioritizing of one category of rights over another. Notwithstanding the emphasis placed on "the significance of national and regional peculiarities and various historical, cultural and religious backgrounds" by leaders of Asian states, as expressed in the Final Declaration of the Regional Meeting for Asia of the 1993 World Conference on Human Rights (the "Bangkok Declaration"), ${ }^{11}$ Article 5 of the Vienna Declaration explicitly addresses, and disposes of, two issues central to the debate on the universality of human rights: firstly, whether there exists a core set of universally applicable fundamental rights (the answer is in the affirmative), and secondly, the nature of the interrelationship between the different types or 'generations' of rights.

It is widely acknowledged that no one civilization, religion or philosophy has a monopoly on the notion of the importance of human dignity and the protection thereof, ${ }^{12}$ yet the origins of the modern human rights movement are generally traced to the articulation in the seventeenth and eighteenth centuries within the Western European liberal democratic tradition of certain specific rights and freedoms which derive from natural rights and natural law philosophies and which constitute the classic 'civil liberties' or so-called 'first generation' civil and political rights. The presumption was that such rights were natural, inherent and inalienable, the birthright of all men; although, as the foregoing suggests, these egalitarian ideals did not necessarily extend to women, children, slaves, the colonized, the poor, the handicapped, or the mentally ill.

\footnotetext{
71993 Vienna Declaration and Programme of Action on Human Rights: UN Doc A/CONF.157/23 (1993).

8 Ibid., Preamble.

9 Ibid., Part I, Article 1.

10 Ibid.

${ }^{11}$ Final Declaration of the Regional Meeting for Asia of the 1993 World Conference on Human Rights: UN Doc A/CONF.157/ASRM/8-A/CONF.157/PC/59, Article 8.

${ }_{12}$ See A. Robertson and J. Merrills, Human Rights in the World (Manchester: Manchester University Press, 1996), at Chapter 1, and A. Sen, "Human rights and Asian values", The New Republic, 14 - 21 July 1997.
} 
While the late nineteenth century onwards saw an emerging recognition at national level of certain individual rights or protections for specific individuals, ${ }^{13}$ the position at the international level was very different. Prior to World War II international law was, subject to very limited exceptions, ${ }^{14}$ exclusively concerned with the facilitation and regulation of relations between States; its scope did not extend to the treatment by States of persons within their own borders, such matters being considered as falling strictly within the parameters of domestic jurisdiction. ${ }^{15}$ A growing realization of the extent of the human rights violations perpetrated during the war provided the catalyst for change; the end of the war signalled the start of the use of international law to identify and set legally binding universal human rights standards and to create mechanisms to implement, monitor and enforce such rights. The 1945 Charter of the United Nations introduced for the first time in an international instrument the notion that the promotion and protection of fundamental human rights was a legitimate matter of concern of the international community and of international law. ${ }^{16}$ From its inception in 1945 the United Nations has played a crucial role in the development of international human rights law.

The end of World War II also marked the start of a long process, beginning with the International Military Tribunals at Nuremberg and Tokyo and culminating in the recent creation of the International Criminal Court, of seeking to hold individuals accountable under international law for gross human rights violations committed both in war and in peacetime. This principle was reaffirmed and reinforced in the 1998 Rome Statute for the International Criminal Court which has, in addition to war crimes, jurisdiction over the crime of genocide and crimes against humanity regardless of whether commission occurs in the course of armed conflict or in peacetime. ${ }^{17}$ The Rome Statute, which came into force on 1 July 2002, has been signed by 139

13 For example, the 1829 British prohibition of the custom of Sati (widow immolation) in India; the United Kingdom's 1884 Reform Act which established the principle of "one man, one vote" and gave most, but not all, adult males the right to vote (universal male suffrage was not introduced in Britain until 1918, universal female suffrage in 1928).

14 The abolition of slavery; the 1864 Geneva Convention for the Amelioration of the Condition of the Wounded on the Field of Battle and the subsequent development of international humanitarian law; the establishment in 1919 of the International Labour Organization and the subsequent promulgation of international standards for the protection of workers; the establishment by the League of Nations of mandated territories and agreements for the protection of minorities; See Robertson and Merrills, n. 12, at 15-23.

15 See Robertson and Merrills, n. 12, at 1-2; see also D. McGoldrick, The Human Rights Committee (Oxford: Clarendon Press, 1996), at 4, and A. Steiner and P. Alston, International Human Rights in Context (Oxford: Oxford University Press, 2002), at 126-135.

${ }^{16}$ Charter of the United Nations 1945, Preamble, Article 1, Article 55, Article 56, Article 62, Article 68, Article 76. The inclusion in the Charter of references to human rights was largely at the behest of the Latin American and smaller states, NGOs and pressure groups. Suggestions that a "Bill of Rights" be incorporated in the Charter were rejected. See McGoldrick, n. 15, at 4 and J. Rehman, International Human Rights Law: A Practical Approach (Harlow: Longman, 2003), at Chs. 2 and 3.

17 Rome Statute of the International Criminal Court, Articles 5-8. UN Doc A/Conf 183/9. 
states and ratified by 92 to date. ${ }^{18}$ The level of signing and ratification of the Rome Statute by South Asian states is poor: Afghanistan has acceded to the Statute; Bangladesh has signed but not ratified it, and India, Pakistan, Sri Lanka, and Nepal have neither signed nor ratified the Statute.

On 9 December 1948 the UN General Assembly adopted the Convention on the Prevention and Punishment of the Crime of Genocide. ${ }^{19}$ This Convention defined the crime of genocide for the first time in an international instrument of binding nature and provided for individuals accused of genocide to be tried either in national courts or by a putative international criminal tribunal, although the Convention itself contained no provision for the creation of such an organ. Just a day later the Universal Declaration of Human Rights was adopted by the UN General Assembly as a "common standard of achievement for all peoples and all nations". ${ }^{20}$ Intended as an authoritative interpretation of the human rights provisions of the United Nations Charter rather than as a legally-binding instrument, the Universal Declaration was adopted without dissenting votes, albeit eight abstentions, ${ }^{21}$ despite encompassing a wide range of rights in addition to the classic civil and political rights: economic, social and cultural rights ('second generation' rights) such as the right to work, the right to social security, the right to an adequate standard of living, the right to education, and the right to leisure; and 'third generation' or group rights such as the right to a suitable social and international order. ${ }^{22}$

The intention of following the Universal Declaration with a single norm-setting instrument and a second instrument establishing mechanisms for enforcement was disrupted by the onset of the Cold War; in the arena of human rights, this manifested itself in the form of intense ideological disagreement over the nature and relative importance of civil and political versus economic and social rights, the justiciability of the two types of rights, and the methods for implementing, monitoring and enforcing them. At the same time, the post-WWII decolonization process resulted in the arrival on the world stage of newly independent States, primarily from the South, many of whom prioritized economic and social rights over civil and political rights. ${ }^{23}$ The inability of the world community to reach agreement on a single, comprehensive rights instrument underwritten by uniform mechanisms for enforcement resulted in the adoption in 1966, a full eighteen years after the Universal Declaration, of two legally-binding standard-setting instruments, one on economic, social and cultural rights and the second on civil and political rights, each containing separate and

\footnotetext{
${ }^{18}$ See website of the Rome Statute of the International Criminal Court: http://www.un.org/law/icc/ statute/romefra.htm.

19 Adopted 9 December 1948. Entered into force 12 January 1951. GA Res. 206A III. 78 U.N.T.S. 277. The Genocide Convention has been ratified and/or acceded to by Afghanistan, Bangladesh, India, Nepal, Pakistan and Sri Lanka.

${ }^{20}$ Adopted 10 December 1948. GA Resolution 217 A(III). UN Doc.A/811.

${ }^{21}$ Byelorussia, Czechoslovakia, Poland, Ukraine, USSR, Yugoslavia, Saudi Arabia, and South Africa.

${ }^{22}$ See Rehman, n. 16, at Chap. 3.

23 See McGoldrick, n. 15, at Chap. 1.
} 
different mechanisms of monitoring and enforcement; ${ }^{24}$ together with the Universal Declaration, they form the International Bill of Rights. It is noteworthy that in practice few States have ratified one Covenant yet not the other, an indication that States indeed generally consider the rights in both Covenants to be interrelated and indivisible. $^{25}$

In 1965 the UN-sponsored International Convention on the Elimination of All Forms of Racial Discrimination (the "Race Convention") was adopted. ${ }^{26}$ Over the course of the next three decades the series of UN-sponsored, specialized international human rights treaties that followed the Race Convention and the two Covenants provided for the elimination of discrimination against women, ${ }^{27}$ the prohibition of torture, ${ }^{28}$ and the rights of the child. ${ }^{29} \mathrm{~A}$ further Convention, on the rights of migrant workers and their families, came into force on 1 July $2003 .{ }^{30}$ This network of free-standing treaties complements an array of bodies and mechanisms that are part of, or derive from, the Charter and the UN structure itself. Between them these treaties, their monitoring bodies ${ }^{31}$ and the various UN bodies and mechanisms ${ }^{32}$ purport both to set universal international human rights norms, and to monitor and enforce them.

\footnotetext{
${ }^{24}$ International Covenant on Economic, Social and Cultural Rights. Adopted 16 December 1966. Entered into force 3 January 1976. GA Res. 2200A (XXI). UN Doc. A/6316 (1966). 999 UNTS 3. International Covenant on Civil and Political Rights. Adopted 16 December 1966. Entered into force 23 March 1976. GA Res. 2200A (XXI). UN Doc. A/6316 (1966). 999 UNTS 171.

25 Amongst South Asian States, Pakistan is alone in having failed to ratify either Covenant. For full State-by-State ratification details see http://www.bayefsky.com/.

${ }^{26}$ Adopted 21 December 1965. Entered into force 4 January 1969. GA Res. 2106 (XX). 660 UNTS 195. Ratified by Afghanistan (6 July 1983); Bangladesh (11 June 1979); India (3 December 1968); Nepal (30 January 1971); Pakistan (21 September 1966); Sri Lanka (18 February 1982).

27 Convention on the Elimination of All Forms of Discrimination Against Women. Adopted 18 December 1979. Entered into force 3 September 1981. GA Res. 34/ 180. UN Doc. A/34/46. 1249 UNTS 13. Ratified by Afghanistan (1 April 1987); Bangladesh (6 November 1984); India (9 July 1993); Nepal (22 April 1991); Pakistan (12 March 1996); Sri Lanka (5 October 1981).

${ }^{28}$ Convention Against Torture and other Cruel, Inhuman or Degrading Treatment or Punishment. Adopted 10 Dec.1984. Entered into force 26 June 1987. GA Res. 39/46. UN Doc. A/39/51 (1984). 1465 UNTS 85. Ratified by Afghanistan (1 April 1987); Bangladesh (5 October 1998); Nepal (14 May 1991); Sri Lanka (3 January 1994). Signed but not ratified by India (14 October 1997).

29 Convention on the Rights of the Child. Adopted 20 November 1989. Entered into force 2 September 1990. GA Res. 44/25. UN Doc. A/44/49 (1989). 1577 UNTS 3. Ratified by Afghanistan (28 March 1994); Bangladesh (3 August 1990); India (11 December 1992); Nepal (14 September 1990); Pakistan (12 November 1990); Sri Lanka (12 July 1991).

${ }^{30}$ International Convention on the Protection of the Rights of All Migrant Workers and Members of Their Families. Adopted 18 December 1990. Entered into force 1 July 2003. GA Res. 45/148. UN Doc. A/48/49 (1993).

${ }^{31}$ Committee on the Elimination of All Forms of Racial Discrimination (CERD); Committee on Economic, Social and Cultural Rights; Human Rights Committee (HRC); Committee on the Elimination of All Forms of Discrimination Against Women (CEDAW); Committee Against Torture (CAT); Committee on the Rights of the Child (CRC). For a full discussion of the treaty monitoring bodies see Rehman, n. 16, at Ch. 4, 5, 10-15.

${ }^{32}$ See Rehman, n. 16, at Ch. 2.
} 
Despite such achievements at international level in the setting of standards and the establishment of implementation, monitoring and enforcement mechanisms, the realization at regional and national level of universal human rights as envisaged in the 1993 Vienna Declaration remains impeded by a variety of factors, many of which are pertinent to the relatively poor progress of the enjoyment of human rights in the context of South Asia. Across the region there are widespread violations of international human rights treaty obligations; these may result from institutional failure, or from being committed by agents of the State such as the police and the military or by private individuals whose behaviour the State fails to prevent or punish. At national level the lack of accessible and effective remedies, coupled with a lack of political will on the part of national and local law enforcement bodies and, at times, also of the judiciary to implement remedies that are in theory available, continues to render basic rights illusory, whilst at international level enforcement mechanisms are often inaccessible, slow and ultimately ineffective since the power to reach a judicial settlement or impose sanctions is lacking. Universal ratification of international human rights treaties has still not been achieved, although some, such as the Convention on the Rights of the Child, have achieved near-universal status; conversely, where States have ratified, there is widespread failure fully to implement in their national legal systems the human rights obligations which they have undertaken at international level. Reservations incompatible with the object and purpose of the treaty ${ }^{33}$ continue to be entered to international human rights treaties, a problem particularly acute in relation to the Convention on the Elimination of all Forms of Discrimination against Women (the "Convention on Women"). The practice of entering such reservations is commonly defended and justified on the grounds of culture, tradition or religion. ${ }^{34}$ The 1993 World Conference on Human Rights urged both the universal ratification of international human rights treaties and the avoidance as far as possible of resort to reservations. ${ }^{35}$

\section{RESPECT FOR HUMAN RIGHTS IN SOUTH ASIA: CURRENT ISSUES}

The issues examined by the Manchester symposium centre on the extent to which the current situation regarding human rights in South Asia is compatible with universal human rights and fundamental freedoms as articulated in the 1993 Vienna Declaration and Programme of Action, the threat to human rights posed by the current wave of

\footnotetext{
${ }^{33}$ On treaty reservations generally, see Vienna Convention on the Law of Treaties, adopted 22 May 1969, entered into force 27 January 1980, 1155 UNTS 331; advisory opinion on Reservations to the Genocide Convention, ICJ Rep. 1951, at 15.

${ }^{34}$ See for example the reservation of Bangladesh to Articles 2 and 16(1)c of the CEDAW on the grounds that these Articles conflict with Sharia law.

${ }^{35}$ See n. 7, Part I, Article 26. Among South Asian states ratification of all but the Migrant Workers' Convention is universal, apart from India, which has signed but not ratified the Torture Convention, and Pakistan, which has neither signed nor ratified the two International Covenants and the Torture Convention.
} 
globalization, ${ }^{36}$ and how respect for and effective enjoyment of human rights in the sub-continent might be improved. South Asia is home to one in five of the world's population. It has huge diversities of language, religion, race, and culture. It has experienced invasion, conquest, immigration and emigration, colonialism, partition, conflict, territorial disputes, and terrorism; it now finds itself at the epicentre of the phenomenon known as globalization. It exhibits, and permits, extremes of poverty, social exclusion, wealth, and power. It is also a region where the human rights of its inhabitants are regularly violated and where remedies for such violations are all too frequently denied, despite de jure protection provided at national level under State Constitutions $^{37}$ and by a complex web of legislation, regulations, and statutory and constitutional bodies and institutions.

\subsection{Globalization, poverty and the right to development}

Many millions in the region lack a standard of living adequate for their health and well-being, including housing, access to clean and safe water, medical care and access to basic education; these in turn result in social exclusion. ${ }^{38}$ Security of food and nutrition is of crucial importance in the region as a whole, particularly for the most impoverished. Production is generally good, but equality of access to food, and to distribution, remains poor. Whilst starvation deaths are relatively rare, chronic under-nourishment and malnourishment, especially amongst children, are endemic across the region. The 1993 World Conference on Human Rights affirmed that extreme poverty and social exclusion constitute a violation of human dignity. ${ }^{39}$ All States have a duty to promote the human rights of the poorest and to foster participation by the poorest people in the decision-making processes of the communities where

36 See U. Baxi, The Unreason of Globalization and the Reason of Human Rights (Mumbai: Dept. of Sociology, University of Mumbai, 1999); see also UN Sub Commission on the Promotion and Protection of Human Rights, Preliminary Report by J. Oloka-Onyango and D. Udagama on Globalisation and its impact on the full enjoyment of human rights (E/CN.4/Sub.2/2000/13); Committee on Economic, Social and Cultural Rights, Statement on globalisation and economic, social and cultural rights, 11 May 1998.

37 The constitutions of Bangladesh, India, Nepal, Pakistan, and Sri Lanka distinguish between civil and political rights, typically justiciable and expressed as fundamental rights; and economic, social and cultural rights, typically non-justiciable and expressed as fundamental or directive principles of State policy.

38 See for example the 2001 India Census according to which there are 321 million illiterate people in India out of a population of 1 billion; only $12.3 \%$ of rural households have electricity, toilet and safe drinking water; half of all children are malnourished; one third of the population lives below the national poverty line. See P. Radhakrishnan, India Development Report (New Delhi: OUP India, 2002); Pakistan has a population of some 140 million, $59 \%$ of whom are illiterate; one third do not have access to safe water; $38 \%$ of children under five are malnourished and $34 \%$ of the population lives below the national poverty line.

39 See n. 7, Part I, Article 25; see also n. 7, Part I, Article 14: "The existence of widespread extreme poverty inhibits the full and effective enjoyment of human rights; its immediate alleviation and eventual elimination must remain a high priority for the international community." 
they live. ${ }^{40}$ The World Conference on Human Rights also reaffirmed the right to development, as established in the UN Declaration on the Right to Development, ${ }^{41}$ as a universal and inalienable right and as an integral part of fundamental human rights, and called on the world community to help alleviate the external debt burden of developing countries in order to supplement the efforts of the governments of such countries. ${ }^{42}$ Conversely, a lack of development is no excuse for human rights failures and abuses; the right to development requires effective policies at national level as well as equitable economic relations and a favourable economic environment at the international level, and the lack of development should not be invoked to justify the abridgment of internationally recognized human rights. ${ }^{43}$

\subsection{Human rights in a fractured society: democracy, the rule of law, govern- ance and human rights ${ }^{44}$}

Democracy, development and respect for human rights and fundamental freedoms are interdependent and mutually reinforcing. ${ }^{45}$ The strengthening by national governments of national legislation, institutions and infrastructures that uphold the rule of law and democracy is a prerequisite to the individual enjoyment of universal human rights and fundamental freedoms. ${ }^{46}$ The discussion in this sub-section is extracted from the symposium paper presented by D.A. Ghanchi, former Pro-Vice-Chancellor of North Gujarat University, ${ }^{47}$ in which he examines the impact of sectarian friction, polarization and societal fragmentation on democracy, the rule of law and human rights in India. Ghanchi presents examples of violations of the right to life in its broadest sense as a means of examining the fault-lines in Indian society. Describing India as "a fractured society", he argues that administrative inefficiency, corruption, the arbitrary exercise of power by State authorities, and divisive, manipulative and self-serving politics threaten to undermine the rule of law, democracy, and human rights.

The Indian Constitution of 1950 laid the foundation for a pluralistic, multi-cultural, secular, democratic society. Its building blocks were to be a polity based on the rule of law; a society based on freedom, justice, equality, social security, and non-discrimination; an economy based on the equity, egalitarianism and prosperity of all; a government free from corruption, nepotism, favouritism, communalism, and inefficiencies; and an education system that should be universal, compulsory and free

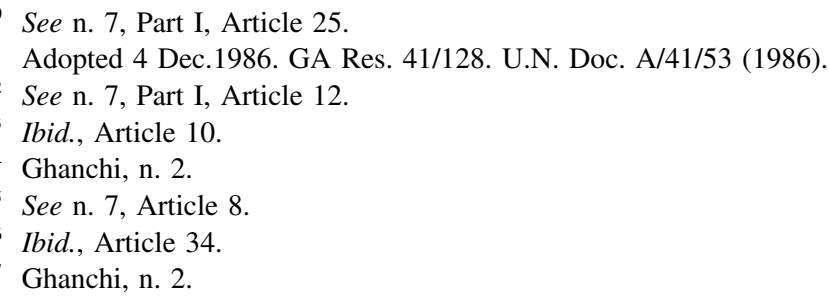


at the primary stage, and which should act as a tool of national development: economic, social, cultural, moral, and spiritual. Civil and political rights were enshrined in Articles 12-35 of the Indian Constitution as "Fundamental Rights" and made enforceable by law, ${ }^{48}$ while economic and social rights were listed as "Directive Principles of State Policy". ${ }^{49}$ However, Ghanchi finds that whilst India has one of the most democratic Constitutions in the world, "its institutions - the legislature, the executive and the judiciary, and their operators, namely the politicians, the bureaucracy and the functionaries in every domain of administration, government and management - have proved abysmally short in performance". ${ }^{50}$

\subsubsection{The right to life}

At its most elementary level the right to life refers to bare physical existence. In its most comprehensive form it signifies life with dignity, comprising the availability of adequate food, clean water, shelter and clothing, access to health and medical care, education, a safe and clean environment, good governance, and freedom from corruption as well as freedom from ill-treatment, discrimination and persecution. Violation of any of these elements entails abridgement of the right to life.

\subsubsection{Mass killings, the role of the state and the responsibility of the judiciary}

Mass killings such as have occurred in the recent past in Bosnia Herzegovina and Kosovo are not unknown in India. Countless people have been killed in communal riots that have occurred year after year since Partition in 1947. The right to life of religious minorities is regularly violated as a result of sectarian violence, such as the massacre of Sikhs in Delhi in 1984, and the recent communal violence in Gujarat which has claimed upwards of three thousand lives and destroyed businesses and property worth billions of rupees. At least as great a disaster as the loss of life and property is the damage to the psyche of minorities wrought by fear, hatred, exclusion, and persecution. Communal violence, with the displacement it entails, has resulted in tens of thousands of Indian citizens' becoming refugees in their own country. Muslims are the largest religious minority in India and constitute $12 \%$ of the population or around 150 million people. During the violence in Gujarat in 2002 an estimated five hundred thousand Muslims fled their homes. When the temporary relief camps provided by the State government closed, the displaced were left with no help from the State yet fearful of returning to their demolished homes and businesses in the face of hostility and socio-economic exclusion. ${ }^{51}$ In specific cases the State itself has been found wanting not only for failing to prevent or control com-

48 Constitution of India, Part III.

49 Constitution of India, Part IV.

50 Ghanchi, n. 2, at 2.

51 Ghanchi, n. 2, at 1-3. 
munal violence, but even for direct involvement in it. ${ }^{52}$ Ghanchi is critical of the role of the judiciary for their perceived failure in restraining and punishing the perpetrators of violations of the right to life of the Muslim minority in Gujarat. He cites the observations of a leading lawyer and human rights activist in Gujarat on the role and responsibility of the judiciary:

"As democracy and human rights of all do not depend upon majoritarianism alone, it is the constitutional responsibility and obligation of the judiciary to prevent and deter the latter from encroaching upon and undermining the former." 53

The development of effective national legal systems was identified by the 1993 World Conference on Human Rights as being central to the achievement of human rights. ${ }^{54}$ In the light of this, Ghanchi argues that the apparent reluctance of the State and the judiciary to defend the interests of the Muslim minority in India represents a serious challenge to the rule of law. ${ }^{55}$

\subsubsection{Detained persons: violation of the right to life by state agency ${ }^{56}$}

Aside from what he terms "the phenomenon of mass frenzy" Ghanchi identifies the security forces, police and prison authorities as a significant source of violation of the right to life. An estimated four hundred people a year are killed in incidents involving the police, euphemistically known as "encounters", which occur both inside and outside police stations and jails. Similarly, it is estimated that custodial deaths - deaths and disappearances of prison inmates at the hands of the prison authorities claim a further four hundred lives a year. The torture and ill-treatment of prison inmates are widespread and have "become a regular part of jail administration".

\footnotetext{
${ }^{52}$ Report of the Citizens' Tribunal on the Gujarat Killings, chaired by Mr. Justice Krishna Aiyar, cited in Ghanchi, n. 2, at 2.

${ }_{53}$ Mr. Girish Patel, "The Lawyer's Stance": letter of 10th January 2003 to the Times of India, Ahmadabad, cited in Ghanchi, n. 2, at 3.

${ }^{54}$ See n. 7, Part I, Article 27: "Every state should provide an effective framework of remedies to redress human rights grievances or violations. The administration of justice, including law enforcement and prosecutorial agencies and, especially, an independent judiciary and legal profession.....are essential to the full and non-discriminatory realisation of human rights and indispensable to the processes of democracy and sustainable development."

${ }^{55}$ There are notable exceptions to the criticisms of the judicial system in relation to human rights, for example, the development of Public Interest Litigation, and the judicial activism of the Supreme Court of India in upholding human rights; see V. Vijyakumar in Nirmal, n. 4, at 213-215; S. Sathe, Judicial Activism in India (New Delhi: Oxford University Press, 2002); M. Saharay, Public Interest Litigation and Human Rights in India (Allahabad: Premier Publishing Company, 2000); S. Ahuja, People, Law and Justice: Casebook on Public Interest Litigation, Vols. I and II (Hyderabad: Orient Longman, 1997); K. Verma, Fifty Years of the Supreme Court of India: Its Grasp and Reach (New Delhi: Oxford University Press, 2000), at Chs. 1, 4, 8 and 13; Zahira Habibulla H Sheikh and Another v State of Gujarat and Others, 2004 SCCL.COM 507 (Criminal Appeal Nos. 446-449 of 2004), known as the "Best Bakery" case, arising out of the communal violence in Gujarat in 2000.

56 Ghanchi, n. 2, at 4-5.
} 
Women and children in detention are particularly vulnerable to human rights abuses.$^{57}$ The investigation of custodial deaths and ill-treatment falls within the remit of the National Human Rights Commission (NHRC), established by the 1993 Human Rights Act. Although constituted and funded by central government, the NHRC functions as an independent statutory body. The establishment and work of the NHRC have raised awareness of the extent of police and prison brutality; it has also provided an additional forum for victims to have their complaints heard and addressed.

\subsubsection{Threats to the right to life with dignity: poverty, economic deprivation and lack of education ${ }^{58}$}

Endemic poverty and economic deprivation resulting in malnutrition, disease and death constitute in themselves a gross violation of the right to life. According to a recent report of the National Council of Applied Economic Research, ${ }^{59}$ Thirty per cent of India's population live below the official poverty line and have a daily intake of 1800 calories or less. Infant mortality in India is 71 per 1000 live births. This figure compares poorly with China (30 per 1000), Thailand (25 per 1000) and Sri Lanka (18 per 1000). Child mortality in the first year of life is 111 per 1000. The same report notes India's high level of incidence of diseases such as tuberculosis (TB) and AIDS. Every year there are three million cases of infectious TB and twelve million of the non-infectious type; some five hundred thousand people die from TB alone every year. There are three-and-a-half million HIV-positive persons in India. By 2015 India will have the highest number of HIV-positive persons in the world. Ghanchi cites a report by the Mumbai-based Strategic Foresight Group. It sounds a warning in respect of economic disparities and their impact on human rights in India:

"The disparities engendered by India's current development model have given rise to three broad kinds of economies; the Business Class economy, which gives access to luxuries, constitutes a bare $2 \%$ of the population restricted to fifteen cities. Next comes the Bike economy comprising $15 \%$ of the population. The remaining $83 \%$ belong to the Bullock Cart economy, half of whom barely manage to survive". ${ }^{60}$

Education plays a crucial role in personal empowerment, providing individual and social competencies and imparting dignity to a person's life. However, despite India's constitutional commitment to the provision of education for all six- to four-

57 "The plight of parents": interview of 10th November 2002 with Pervoz Imroz, founder of the Association of Parents of Disappeared Persons, The Times of India, Ahmadabad, at 12, cited in Ghanchi, n. 2, at 4; "Women prisoners and whistle blowers", in the column 'Out of Court', The Times of India, Ahmadabad, 19 January 2003, at 10, cited in Ghanchi, n. 2, at 4.

58 Ghanchi, n. 2, at 5-8.

59 Ibid., at 5.

60 Ghanchi, n. 2, at 6. 
teen-year-olds, $66 \%$ of girls and $50 \%$ of boys in this age group do not attend school, and of those who do, some $50 \%$ drop out by the fourth year of the primary stage. The drop-out rate for girls is higher. One hundred and twenty-five thousand of the six hundred and fifty thousand state primary schools have just one room, and eightyfive thousand have no room at all. According to the 2001 Census the general literacy level in the country is $65 \%$, that among men being $76 \%$ and women $54 \%$. The regional disparities in literacy levels, however, are vast. The literacy rate in Uttar Pradesh is $41 \%$, in Rajasthan $38 \%$ and in Bihar $38 \%$, but $65 \%$ in Tamil Nadu, $76 \%$ in Goa and $90 \%$ in Kerala. Compare these with the literacy rates in other Asian countries such as Thailand (94\%), Sri Lanka (89\%), Indonesia (84\%), and China (78\%). Literacy among women in certain Indian States is extremely low: $25 \%$ in Uttar Pradesh, 22\% in Bihar and 29\% in Rajasthan. India, consequently, has the largest number of illiterate people in the world. The right to life with dignity is seriously jeopardized by the poor average level of education in the country.

\subsubsection{Gender discrimination: violation of the right to life of women and girls}

Under international human rights law it is the duty of States, notwithstanding national and regional particularities and differences in historical, cultural and religious backgrounds, to promote and protect all human rights and fundamental freedoms regardless of their political, economic and cultural systems. ${ }^{61}$ This includes a specific duty to protect the human rights of women and girls, including the elimination of gender-based violence and discrimination, and harmful cultural practices:

"The human rights of women and of the girl child are an inalienable, integral and indivisible part of universal human rights [...] [g]ender-based violence and all forms of sexual harassment and exploitation, including those resulting from cultural prejudice and international trafficking, are incompatible with the dignity and worth of the human person and must be eliminated."

In the sub-continent as a whole, violations of the human rights of women and girls occur on a daily basis in both the public and private spheres, exemplified by practices such as sexual assault and harassment, rape, sexual abuse, child prostitution, forced marriage, domestic violence, dowry killings, so-called "honour killings", and $s a t i$ - all of which are prohibited under national legislation, as well as under international human rights law. The prevailing culture of son-preference across the subcontinent ensures that discrimination against women and girls is entrenched even before birth, a reality reflected in the incidence of female foeticide, female infanticide, with higher malnutrition and death rates, and lower levels of education amongst girl children. The following examples of gender discrimination as a violation of the right

${ }^{61}$ See n. 7, Part I, Article 5.

${ }^{62}$ Ibid., Article 18. 
to life of women in India are taken directly from the symposium paper presented by Ghanchi. ${ }^{63}$

A woman's right to life is violated from the conception stage. Sex testing of foetuses and sex selection abortion is increasing in India despite recent directions by the Supreme Court to various state governments for them to regulate sonogram centres to prevent sex testing of foetuses. ${ }^{64}$ Census figures for the twentieth century reveal a progressive worsening of the sex ratio of women to men. According to the 2001 Census, in the state of Gujarat the sex ratio of women for every 1000 men was 919. In the 0-6 years age group the ratio was 878, and in the Mehansa district of Gujarat the ratio was just 798. At the same time violence and sexual assaults on women are increasing. It is not just illiteracy and backwardness that perpetuate a patriarchal system which discriminates against women. A number of surveys show an even stronger son-preference among the literate and wealthy than among the economically weaker sections. Even in a progressive state like Kerala, despite its history of women's emancipation, the favourable sex ratio of 1058 is slowly changing in favour of men. ${ }^{65}$ Only genuine social and political empowerment can reverse this negative mindset.

Once born, argues Ghanchi, the Indian girl child is subjected to injustices year after year in matters of nutrition, healthcare, education, marriage, and property rights. Early marriage and frequent pregnancies are a threat to girls' physical health and social adjustment. Dowry is a great curse resulting in humiliation, domestic violence and even death. In Delhi alone there are an estimated three hundred and fifty victims of bride burning every year for dowry. Surveys by the International Centre for Research on Women reported in The Times of India of 17 February 2003 estimate that $60 \%$ of women face domestic violence at some point in their marriage, with women from all socio-economic backgrounds affected. Many women are reluctant to go to court for fear of losing custody of their children. ${ }^{66}$

Rape is also prevalent. As many as 15,000 cases were reported in the year 2002. Ghanchi cites Ms. Rhonda Copelon, Director of the International Women's Human Rights Clinic and a panel member on the International Institute for Justice in Gujarat, speaking to The Times of India in January 2003:

"In every society women still fear the stigma of rape. When justice doesn't respond, it pushes them back into the realms of secrecy and shame, and when rapists are allowed to roam free in the community, there is more terror." ${ }^{\prime 67}$

63 Ghanchi, n. 2, at 9-11.

${ }^{64}$ Ibid., at 9 .

65 Ibid.

66 Ibid., at 10 .

67 "Discounting Women ", The Times of India, Ahmadabad, 10 December 2002, at 12, cited in Ghanchi, n. 2, at 10. 
The communal violence in Gujarat in 2002 witnessed a great increase in incidents of rape, including group rape, against Muslim women. Ghanchi cites further from the same interview:

"Great progress in international law has been made in recent years in respect of rape, and it should be applied to Gujarat, for International Criminal Tribunals recognize rape as a crime against humanity, a form of torture, and an act that contributes to genocide." 68

Prostitution is also rife, and is inextricably linked to poverty. India has around one million prostitutes, of whom three hundred thousand are children. Poverty, famine, unemployment and man-made ( $\mathrm{sic}$ ) disasters such as riots encourage this institution. It is estimated that the annual business of prostitutes amounts to Rs.50,000 crore [a crore is ten million], of which Rs.11,000 crore derives from child prostitution. Child prostitution is rising by $10 \%$ every year.

Ghanchi finds a "compensatory solace" in representative democracy. The constitution amended under the regime of the late Prime Minister Rajiv Gandhi in 1986 reserves $30 \%$ of the seats in local civic authorities for women. The lower house of the Indian Parliament (the "Lok Sabha") has had around 4\% to 7\% women members since its inception. However, the achievement of women's equality in society, in the economy and in the polit will take a much longer time. Until then, Ghanchi argues, education, mobilization and agitation must be stepped up. ${ }^{69}$

\subsection{Caste-based discrimination ${ }^{70}$}

The caste system is one of the most urgent and challenging human rights issues facing the region today. Caste-based discrimination, or discrimination on the basis of work and descent (described as the "hidden apartheid"), affects an estimated two hundred and fifty million people in India alone. ${ }^{71}$

Dalits (those belonging to the Scheduled Castes, ${ }^{72}$ or so-called "Untouchables")

\footnotetext{
68 Ibid.

${ }^{69}$ Ibid., at 11.

${ }^{70}$ I am grateful to the Socio-Legal Studies Association, which has enabled me to conduct funded research on the subject of caste discrimination and international human rights law.

${ }^{71}$ See Human Rights Watch, Caste: A Global Concern (New York: Human Rights Watch, 2001); see also S. Narula, Broken People: Caste Violence Against India's "Untouchables" (New York: Human Rights Watch, 1999); M. Srinivas (ed.), Caste: Its Twentieth Century Avatar (New Delhi: Penguin, 1996).

72 "Scheduled Castes" is the legal term adopted by the Constitution of India; " 'Scheduled Castes' means such castes, races or tribes or parts of or groups within such castes, races or tribes as are deemed under Article 341 to be Scheduled Castes for the purpose of this Constitution": Constitution of India, Article 366 (24); "The President may with respect to any State or Union territory, and where it is a State, after consultation with the Governor thereof, by public notification, specify the castes, races or tribes or parts of or groups within castes, races or tribes which shall for the purposes
} 
number one hundred and sixty million in India - more than the entire population of Pakistan. Caste is a phenomenon that occurs not only in India, but across South Asia, in Bangladesh, Nepal, Pakistan, and Sri Lanka, and throughout the South Asian diaspora. Caste-type systems are also found in Japan and parts of Africa. ${ }^{73}$ India, however, contains the greatest number of those affected due to the sheer size of the Indian population; accordingly, this section focuses on the South Asian, specifically the Indian, aspects of the issue.

Notwithstanding academic debate over the origins and definition of caste, it is generally accepted that the caste system is at least two thousand years old and derives from the Hindu division of society into four hierarchical categories, known as the varna system: this has the priests at top of hierarchy, the serfs, cultivators and artisans at the bottom, and the rulers, landowners and warriors, and commoners and traders, in between. Within this framework are some three thousand castes and sub-castes, traditionally social, occupational or territorial in origin, all broadly falling within one of the varnas. In addition there is a large category of people - about one in six of the Indian population - who fall outside the varna system. ${ }^{74}$ These are the people known as "Untouchables" or Dalits, as they choose to call themselves, meaning "the oppressed" or "broken people". Caste is a hierarchical system of institutionalized inequality based on "rigid social stratification into ranked groups defined by descent and occupation". ${ }^{75}$ The connection between caste and occupation is not, however, infallible: people of the same caste have always performed different occupations, and people in the same occupation may belong to different castes. What is not disputed is that caste is based on descent, is thus hereditary and is inalienable. Regardless of occupation, the position of an individual within the caste system is irrevocable. Caste identity is not fluid and the system, certainly in its current form, admits no possibility of caste mobility within an individual's lifetime. No individual can escape the caste of their birth through education, marriage, the acquisition of fame or fortune, or through conversion to another religion. In daily life, caste is the

of this Constitution be deemed to be Scheduled Castes in relation to that State or Union territory, as the case may be.": Constitution of India, Article 341.

73 See Sub Commission on the Promotion and Protection of Human Rights, Working Paper by Mr. Rajendra K.W. Goonesekere on Discrimination based on Work and Descent, E/CN.4/Sub.2/2001/ 16, 14 June 2001, Part I: Communities where discrimination based on work and descent is experienced; see also Expanded Working Paper on Discrimination based on Work and Descent by Mr. Asbjorn Eide and Mr. Yozo Yokota, E/CN.4/Sub.2/2003/24, 26 June 2003, Part I: some affected communities outside of Asia.

${ }^{74}$ See T. Zinkin, Caste Today (London: Oxford University Press, 1962); J. Hutton, Caste in India (Cambridge: Cambridge University Press, 1946); G.S. Ghurye, Caste and Race in India (Bombay: Popular Prakashan, 1969); M. Srinivas, Caste in Modern India (New Delhi: Asia Publishing House, 1962); G. Flood, An Introduction to Hinduism (Cambridge: Cambridge University Press, 1998).

${ }^{75}$ See Caste Discrimination: A Global Concern (New York: Human Rights Watch, 2001), at 1; M. Mendelsohn and M. Vicziany, The Untouchables: Subordination, Poverty and the State in Modern India (Cambridge: Cambridge University Press, 1998), at 15 and Ch. 9; D. Quigley, in M. Searle, M. Chatterjee and U. Sharma (eds.), Contextualising Caste: Post-Dumontian Approaches (Oxford: Blackwell, 1994), at 30-31. 
principal means through which individuals 'place' themselves and others within the social hierarchy. The concept of caste is deeply ingrained in the South Asian psyche, and in the psyche of the diaspora.

Central to the caste system is the notion of Untouchability. This derives from the Hindu concept of ritual purity and pollution. " "Untouchables" are deemed polluted from birth and were, hence, historically assigned and restricted to those occupations, invariably the most menial, deemed 'polluting'. The concept of Untouchability resulted in the development of strict practices of social and physical segregation, caste endogamy, and ritual restrictions on the sharing of food and drink. These rules were stringently enforced by social, economic, religious, political, psychological and physical means. Following Independence, Untouchability was abolished in India by the 1950 Constitution, ${ }^{77}$ but it continues to be practised in the public, social and private spheres in myriad forms across the country, particularly in rural areas. Modern manifestations of Untouchability range from the shockingly violent to the very subtle. In many villages, to this day, Untouchables are forced to live in segregated settlements in the least attractive areas or on the outskirts of a village. They are refused access to public cremation facilities or burial grounds, are forbidden from using roads within caste Hindu areas, and they may not use the same wells and bathing ghats as caste Hindus. In the social sphere, Untouchability continues to be practized in the denial of access to temples and places of worship, the refusal of service in hotels and restaurants, and the social ostracism or exclusion of Dalits in the workplace and in other social situations. The practice of making Dalits use separate drinking glasses is decreasing, yet it still persists in some areas. At the private level, social interaction and integration with caste Hindus remains limited even in urban areas; inter-caste marriage is virtually taboo. In education and employment Dalits suffer discrimination and humiliation. Monitoring groups around the country continue to record incidents of atrocities, often extremely violent, against individual Dalits and against Dalit communities. ${ }^{78}$ Overt caste discrimination is less pronounced in metropolitan areas, where individuals are not known to each other, as caste is not automatically discernible from physical appearance and characteristics. Furthermore, the avoidance of physical contact is impossible, at least in public spaces; but where the cloak of anonymity is removed, discrimination both overt and covert remains widespread. Dalit women and girls suffer the dual oppression of caste and gender, characterized by female infanticide, reduced access to food and education,

${ }^{76}$ See P. Kolenda, Caste in Contemporary India: Beyond Organic Solidarity (Illinois: Waveland Press, 1978), Ch. 4; G. Flood, n. 74, at Chs. 1 and 3, and 219-220.

77 Constitution of India, Article 17.

78 See for example Sakshi Human Rights Watch, Dalit Human Rights Monitor Andhra Pradesh 2002-2003 (Secunderabad: Sakshi Human Rights Watch, 2003); M. Macwan and H. Desai, atrocities on Dalits in Gujarat 1990-3: a Documentation and Evaluation (Surat: Centre for Social Studies, South Gujarat University, 1997). 
rape and sexual assault by high caste men, and by socially-sanctioned child prostitution and sex slavery in the form of the Devadasi system. ${ }^{79}$

Caste is as much an economic as a social phenomenon. The caste system and in particular the practice of Untouchability are intimately linked to poverty. Despite the economic reforms initiated in the 1990s, and the wealth and opulent lifestyle enjoyed by a privileged few, India is still a poor country; according to the 2001 Census, one third of all Indians live below the national poverty line. India is also still predominantly an agricultural society: roughly $70 \%$ of the population live in rural areas. Around half of India's poor are landless agricultural labourers, the majority of whom are Dalits. Three quarters of Dalits live below the poverty line, mostly in rural India. They constitute the poorest and most vulnerable section of Indian society. A high proportion of the rural landless are Dalit women, the lowestpaid section of agrarian society. Furthermore, of an estimated forty million bonded labourers of which fifteen million are children, the majority are Dalits. ${ }^{80}$ A Human Rights Watch study of bonded labour in the silk industry found children aged between six and fourteen working ten to fourteen hours a day, six days a week, the majority of whom were Dalits. Similarly, a recent UNICEF study found that $71 \%$ of children working in brick kilns were Dalits or low castes. Dalits continue to be employed in the most menial of occupations, including occupations such as manual scavenging (the manual removal of night soil from dry latrines), prohibited by law but still accounting for the employment of around one million Dalits, primarily women. ${ }^{81}$

In 1947 India gained its independence and in 1950 a democratic constitution was adopted, drafted by a Committee chaired by Dr. B.R. Ambedkar, himself an Untouchable, one of India's foremost economists and lawyers, and an activist for social justice. ${ }^{82}$ India has an impressive and progressive domestic legal framework in relation to caste that includes constitutional prohibitions on caste discrimination and the practice of Untouchability, ${ }^{83}$ constitutional affirmative action provisions, ${ }^{84}$ a network of legislation banning bonded labour ${ }^{85}$ and the practice of manual scavenging ${ }^{86}$ and providing for the criminalization of untouchability ${ }^{87}$ and atrocities against scheduled castes; ${ }^{88}$ in addition are a range of constitutional and statutory bodies at national and State level concerned with the promotion and protection of human

\footnotetext{
79 Under the Devadasi system young Dalit girls are dedicated to a temple where they are forced to act as prostitutes for upper caste men; see Human Rights Watch, n. 71; see also S. Narula, n. 71, at Ch. IX.

80 See Human Rights Watch, n. 71.

81 Ibid.

82 See B. Chandra et al, India After Independence: 1947-2000 (New Delhi: Penguin, 2000).

83 Constitution of India, Articles 15 and 17.

${ }^{84}$ Ibid., Articles 15(4) and 16(4).

85 Bonded Labour System (Abolition) Act 1976.

86 Employment of Manual Scavengers and Construction of Dry Latrines (Prohibition) Act 1993.

87 Protection of Civil Rights Act 1976 (formerly the Untouchability (Offences) Act 1955).

88 SC and ST (Prevention of Atrocities) Act 1989.
} 
rights, including the rights of Dalits. ${ }^{89}$ Unfortunately, despite the existence of these extensive provisions designed to eliminate caste discrimination and the practice of Untouchability, both remain rife primarily because the existing domestic provisions are neither implemented nor enforced. Victims of discrimination and violence often lack any knowledge of the relevant legal provisions designed to protect them. There is reluctance on the part of victims of discrimination to resort to the law. This is mainly because of the cost, the fear of reprisal, and a lack of confidence in the police and the legal process. The police and lawyers themselves are frequently deficient in familiarity with the relevant law and legal processes. On the part of the police there may be a reluctance, due to caste prejudice, to initiate investigations into allegations of caste discrimination or violence. In its statement to the UN-sponsored World Conference on Racism held in Durban in 2001, the National Human Rights Commission representative referred to the problems of implementation thus:

" $[\mathrm{I}] \mathrm{t}$ is widely recognised that much remains to be done to bring an end to the discrimination and inequality that have been practised for centuries and that this requires both sustained effort and time. There are manifest inadequacies in implementation which are deeply frustrating and painful to the Scheduled Castes and Scheduled Tribes and, indeed, to all Indians who strive to end the injustice that persists in several forms and the atrocities that occur." ${ }^{90}$

Educational and economic empowerment and elevation are also the key tools in the fight against the promulgation of the caste system; these were highlighted by the $\mathrm{NHRC}^{91}$ and by numerous Dalit academics, intellectuals and activists. Ambedkar himself was deeply committed to education as the primary vehicle for the empowerment of Dalits, combined with improvements in their economic status.

At the international level, awareness and understanding of caste-based discrimination have been increasing in recent years, particularly as a result of the efforts of NGOs and activists to raise the profile of this form of human rights violation at the UN-sponsored World Conference on Racism held in Durban in 2001. Article 1(1) of the International Convention on the Elimination of All Forms of Racial Discrimination (CERD) prohibits discrimination inter alia on grounds of descent, a ground proposed by India during the drafting of the Convention. An analysis of the Summary Records of the Monitoring Committees established under the two International Covenants and of the international conventions on race, women and children reveals both an awareness, on the part of those countries affected, of caste-type systems as a source of discrimination, and the extent of concern of the treaty bodies at the de facto perpetuation of caste systems and the practice of Untouchability in various countries around the world. Despite the failure of Dalit activists and their supporters to secure official recognition at Durban that caste discrimination falls within the ambit

\footnotetext{
89 National Human Rights Commission; State Human Rights Commissions and Committees; National Commission for Scheduled Castes and Scheduled Tribes.

90 Journal of the National Human Rights Commission, India, 2002, at 256.

91 Ibid., at 258.
} 
of the Race Convention, developments at the UN level since Durban have been encouraging. In August 2002 the Committee on the Elimination of Racial Discrimination adopted for the first time a General Recommendation on Descent-Based Discrimination, reaffirming the Committee's view that discrimination based on descent, prohibited under Article 1(1) of the Race Convention, includes "discrimination against members of communities based on forms of social stratification such as caste and analogous systems of inherited status which nullify or impair their equal enjoyment of human rights." 92 In August 2003 the UN Sub-Commission on the Promotion and Protection of Human Rights, recalling the two expert working papers on discrimination based on work and descent submitted to it in 2001 and 2003 respectively, ${ }^{93}$ adopted a Resolution on Discrimination based on Work and Descent ${ }^{94}$ calling for the preparation of a third expert working paper to examine legal, judicial, administrative, and educational measures taken by the Governments concerned, to identify additional communities affected by this form of discrimination, and to prepare a draft set of principles and guidelines for all relevant actors in cooperation and collaboration with, inter alia, the Race Committee, the International Labour Organization and UNESCO. The resolution further calls on States to formulate and implement at the national, regional and international level new and enhanced policies and plans of action to effectively eliminate discrimination based on work and descent, taking into account the measures proposed in General Recommendation XXIX and to give widespread publicity to the General Recommendation. Caste-based discrimination is also actively being addressed by the UN Working Group on Contemporary Forms of Slavery ${ }^{95}$ and by the International Labour Organization. The issue of caste-based discrimination, particularly the issue of inadequate implementation and enforcement of domestic provisions and fulfilment of international human rights obligations pertaining to caste, demands to be addressed with a continued sense of urgency at the national, regional, and international levels and requires to be tackled simultaneously on political, legal, social, cultural, economic, and religious fronts.

\subsection{Religious minorities: a case study of the treatment of the Ahmadiyya Muslim community in Pakistan'}

International human rights law imposes on States a duty to protect the rights of religious, linguistic, racial, and ethnic minorities, and an obligation to ensure that persons belonging to minorities may exercise fully and effectively all human rights and fundamental freedoms without discrimination. This

\footnotetext{
92 CERD General Recommendation XXIX; CERD/C/61/Misc 29.

93 See UN Sub-Commission on the Promotion and Protection of Human Rights, Working Paper by A. Eide and Y. Yokota on Discrimination Based on Work and Descent (E/CN.4/Sub.2/2003/24).

94 UN Sub-Commission on the Promotion and Protection of Human Rights; Resolution 2003/22 of 13 August 2003. Discrimination based on work and descent.

95 See Report E/CN.4/Sub.2/2003/31.

96 Malik, n. 2.
} 
includes the right of religious minorities to profess and practice their own religion. ${ }^{97}$ Nevertheless, discrimination against and the persecution of religious minorities, and the rise of sectarian politics, constitute a serious threat to the rule of law and to peace and stability in the region. The following discussion is extracted from the symposium paper by Nadeem Malik; ${ }^{98}$ it examines the progressive decline in religious rights in Pakistan since 1947, focussing on the treatment of the Ahmadiyya Muslim Community as a case study. ${ }^{99}$

Ahmadi Muslims number around four million in Pakistan and have always considered themselves as belonging to the Muslim ummah, or wider "community of Muslims". ${ }^{100}$ The Ahmadiyya Muslim community has been described as "the most persecuted Muslim religious group today", ${ }^{101}$ unique as a religious community, Malik claims, because the discrimination that Ahmadis suffer has been made entirely legal - indeed, it has been written into the national Constitution. The Ahmadiyya Community was founded in India in the late 1880s by the Muslim theologian and scholar Hazrat Mirza Ghulam Ahmad of Qadian (1835-1908) against a backdrop of declining Muslim fortunes in India exacerbated by the social and cultural insularity, anti-modernity and anti-British stance of the Muslim religious leaders, the orthodox clergy or ulema. As Malik explains, Hazrat Mirza Ghulam Ahmad espoused a fundamentally different interpretation of the identity of the Promised Messiah to that of the Sunni Muslim majority; alarmed by his unorthodox doctrinal interpretations and religious writings - and by the popularity of his teachings, which threatened their political authority and grip on the general body of Muslims - the orthodox clergy declared Hazrat Mirza Ghulam Ahmad a heretic and denounced his followers as apostates.

Muhammed Ali Jinnah, the first President of independent Pakistan, conceived of Pakistan as a liberal, secular nation rather than as a theocracy. Malik cites Jinnah's first address to the new Constituent Assembly of Pakistan in August 1947 in which the non-sectarian character of Pakistan was addressed:

"You are free. You are free to go to your temples. You are free to go to your mosques or to any other places of worship in this State of Pakistan. You may belong to any religion or caste or creed - that has nothing to do with the business of the State. We are starting in the days when there is no discrimination, no distinction between one community and another, no discrimination between one caste or creed and another. We are starting with this fundamental principle, that we are all citizens and equal members of one state". ${ }^{102}$

97 See n. 7, Part I, Art 19.

98 Imperial College, University of London, United Kingdom.

99 Malik, n. 2.

100 See A.M. Khan, "Persecution of the Ahmadiyya community in Pakistan: an analysis under international law and international relations", 16 Harvard Human Rights Journal (2003), at 217.

${ }^{101}$ Donna E. Artz, "Heroes or heretics: religious dissidents under Islamic law", 14 Wisconsin International Law Journal (1996), 349, at 408, cited in Malik, n. 2, at 2.

102 Malik, n. 2, at 6. 
Khan recounts how this vision was reflected in the approach of Pakistan during the drafting of the Universal Declaration of Human Rights, adopted in 1948. Whereas the Saudi representative opposed the right contained in Article 18 of the UDHR to change one's religion as contrary to Islamic law (or Shari'a) and a product of western thinking, the Pakistani representative - Pakistan's first foreign minister and an Ahmadi - embraced the right to freedom of conscience as entirely consistent with Islam's rejection of any compulsion in matters of faith. ${ }^{103}$

Pakistan is a country of one hundred and fifty-five million people divided on religious and ethnic lines. Sunni Muslims form 77\% of the population, 20\% are Shias and one per cent Ahmadi, with Hindus and Christians together amounting to between two and three per cent. At its inception, the modern Pakistan was ethnically, linguistically and religiously diverse, a situation requiring astute and delicate handling if the country were to develop in peace and harmony. Malik argues that with Jinnah at the helm the centrifugal forces inherent in a nation with such strong ethnic and religious diversity were subdued. With the premature death of Jinnah in 1948, however, came a more or less permanent crisis of leadership and a progressive erosion of the vision of a modern, secular, tolerant, and inclusive Muslim country. In parallel with religious intolerance, ethnic struggles also emerged. Fifty-five per cent of the population are Punjabi and the remainder a mixture of Pathan (10\%), Sindhi (18\%), Mohajir (10\%), and Baluchi (2\%). In 1947 the Punjab was more advanced than other regions of Pakistan in terms of general educational and political development; consequently, Punjabis dominated the political, economic and military landscape. The ethnic minorities felt increasingly marginalized by the majority Punjabis, and secessionist tendencies that were mild at Pakistan's inception have reached crisis point in recent years. ${ }^{104}$

In March 1949, following the death of Jinnah, the Constituent Assembly passed the so-called "Objectives Resolution" which declared that the first Constitution of Pakistan should be based on the "ideals of Islam", although religious freedom for non-Muslims would be provided for. ${ }^{105}$ Malik refutes the denials of the government at the time that the resolution implied a theocratic State, arguing that it was clear that the resolution was indeed the first step in that direction. Consequently, he argues, demands by Muslim separatists that Ahmadis be declared non-Muslim became both a rallying point for fundamentalist parties and the principal weapon in the campaign to transform the country into an Islamic theocracy. ${ }^{106}$ In 1962 the so-called 'repugnancy clause' was added to the Constitution, a significant move, Malik contends, towards theocracy: "No law shall be repugnant to the teachings and requirements of Islam as set out in the Qur'an and Sunnah, and all existing laws shall be brought into conformity therewith."107

\footnotetext{
103 Khan, n. 100.

104 Malik, n. 2, at 7-9.

105 The "Objectives Resolution" was incorporated into the Constitution of Pakistan as Article 2

by Presidential Order No.14 of 1985; see Malik, n. 2, at 14.

106 Ibid.

107 Constitution of Pakistan, Part IX, Article 227.
} 
In 1973 the new Constitution, introduced following the secession in 1971 from West Pakistan of East Pakistan to become Bangladesh, was amended by the inclusion of a legal definition of non-Muslims that covered Ahmadis as well as Christians, Hindus, Sikhs, Buddhists, Parsis, the Baha'i community, and the Scheduled Castes. ${ }^{108}$ Ahmadis were thus explicitly deprived by law of their identity as Muslims. In 1978, electoral reforms were introduced providing for separate electorates for non-Muslims in the National and Provincial Assemblies. Members of minority religions could vote only for candidates from a minority list. As a result, Malik argues, majority Muslim candidates had no incentive to appeal to religious minorities. This has severely affected Christians, Hindus and other religious communities by further diminishing the already weak voice that these communities had in politics. According to Malik, the impact of these reforms on Ahmadis, who consider themselves to be Muslims and who therefore refuse to register or vote as non-Muslims, has been complete disenfranchisement, yet in 2002 President Musharraf confirmed that the separate electoral system and the legal status of Ahmadis under the Constitution would remain unchanged.

In 1984 President Zia ul Huq, in power since 1977 following a military coup, pushed through parliament a number of ordinances targeting religious minorities, of which two (collectively referred to as Ordinance XX) amended Pakistan's Penal Code and were aimed specifically at Ahmadis. ${ }^{109}$ Ordinance XX provided for the imposition of a prison sentence and a fine for blasphemy defined, in relation to Ahmadis, as the use of Islamic terminology and references whether spoken, written or by "visible representation", directly or indirectly posing as Muslims, referring to their faith as Islam or in any manner whatsoever "outraging the feelings of Muslims". Ahmadis were thus prohibited from behaving and conducting themselves as Muslims; their very existence as Ahmadi Muslims was criminalized. With the introduction in 1986 of the Criminal Law Act, together with ordinance XX known as the "Blasphemy Law", the penalty for blasphemy was increased to death. ${ }^{110}$

Malik argues that once a culture of discrimination and persecution is engendered in a society it seldom remains confined to a specific target, particularly where it has the explicit backing of the Constitution and the law; the terminology of the "Blasphemy Law" in Pakistan is such that even though Ahmadis were the intended targets the law can be used against anyone who "outrages the religious feelings of Muslims". Ahmadis have been subjected on religious grounds to decades of persecution in Pakistan. It was inevitable that Christians and Hindus would also become targets of the rising extremist Muslim groups. Thus, in parallel with the state-supported persecution of Ahmadis in Pakistan there has been increased agitation against Christians, Hindus, and Shia Muslims over the same period. ${ }^{111}$

Christians and Hindus in Pakistan suffer widespread discrimination in all areas of public and private life. The vast majority of Christians and Hindus belong to the

108 Ibid., Part X11, Ch. 5, Article 260(3)(a) and (b).

109 Pakistan Penal Code, Sections 298(b) and 298(c).

110 Pakistan Penal Code, Section 295(c).

111 Malik, n. 2, at 22-23. 
poorest social classes in Pakistan, a situation compounded by the social segregation and isolation of Pakistan's various religious and ethnic communities, which further alienates minority communities from the mainstream. Christians and Hindus face problems at every level. Even if they can afford schooling for their children they continue to suffer religious discrimination and poor career prospects. Since Partition in 1947 the Hindu population of Pakistan has shrunk considerably, primarily through migration and through conversion to Christianity or Islam. At various periods of conflict with India large numbers of Hindus, fearing for their lives, have migrated across the border; few have returned. Anti-Muslim communal violence in India exacerbates this situation, leading to revenge attacks on Hindus in Pakistan. Hindus once accounted for more than five per cent of the population of Pakistan, but now they amount to no more than about one per cent, mostly in the Sind province. Christians suffer greater targeted violence from extremist Muslim groups because they are perceived as 'Westerners', an image bolstered in the minds of extremist groups by the fact that numerous Christian churches based in the West are active in Pakistan, particularly among poor villagers. Christians are especially vulnerable during times of anti-Western sentiment. Following the American invasion of Afghanistan in 2002 and the Anglo-American invasion of Iraq in 2003 numerous Christian churches in Pakistan were attacked and dozens of Christians were killed or injured by extremist Muslim groups. Yet Christians benefit from the fact that there are many highly respected and well-funded Christian schools, financed by churches based in the West, which provide a high level of education. Although some Christians attend these schools, the vast majority are Muslim children from rich families for whom attendance at such schools has become a status symbol. Malik explains that Shias have not been declared non-Muslims and hence still enjoy a better position than Ahmadis; in the prevailing climate of religious intolerance, however, the Shias have increasingly come under attack. The ulema largely follow the Wahabi faith of Saudi Arabia, associated with an anti-Shia stance, and the re-emergence of Shia Iran as a regional power has fuelled a divide with ancient roots in the history of Islam. ${ }^{112}$ This has led to violent clashes in some parts of Pakistan, particularly in Karachi during the 1990s.

Today, argues Malik, religious discrimination is enshrined in Pakistan's constitution. In parallel with the persecution of Ahmadi Muslims other religious communities have also come under increasingly violent attack. Repeal of the laws and Constitutional amendments that infringe upon religious rights and a return to the first Constitution of Pakistan would comprise the first step in the reversal of that trend.

\section{REGIONAL COOPERATION, PEACE AND HUMAN RIGHTS ${ }^{113}$}

The fundamental link between human rights, on the one hand, and stability and peace, on the other, first identified in the Charter of the United Nations, is reiterated

112 Ibid., at 24-25.

113 Rehman, n. 2. 
in the 1993 Vienna Declaration. It declares that efforts towards the universal respect for and observance of human rights and fundamental freedoms contribute to the stability and well-being necessary for peaceful and friendly relations among nations. ${ }^{114}$ As Javaid Rehman ${ }^{115}$ reminds us, in Europe regional organizations such as the European Union, the Council of Europe, and the Organization on Security and Cooperation in Europe (OSCE) have been the driving force for economic development, security and greater protection of human rights. ${ }^{116}$ The following sub-section is extracted from the symposium paper presented by Javaid Rehman ${ }^{117}$ on the role and contribution of regional institutions in facilitating cooperation and dialogue as a means of resolving conflicts and disputes and of combating terrorism and human rights abuses, and the possibility of South Asia's following the European example of regional cooperation.

\subsection{South Asian Association for Regional Cooperation (SAARC): Constitu- tionalism, Regional Peace and Human Rights}

\subsubsection{Background}

South Asia is beset by political and constitutional instability, largely a heritage of the colonial period and the subsequent process of decolonization, compounded by boundary and territorial disputes, conflict along ethnic, religious and linguistic lines, widespread violations of civil and political, economic, social and minority rights, and also by international and regional terrorism, which presents a major challenge to stability in the region. British India, which formed the core of present day SouthAsian States, was a conglomeration of around 600 autonomous principalities and princely states of varying sizes, along with unified provinces. The partition of India led the way to decolonization in the rest of South Asia and cost a million lives. ${ }^{118}$

\footnotetext{
114 See n. 7, Article 6.

115 Javaid Rehman, Professor of International Law, University of Ulster, United Kingdom.

116 See T. Hartley, The Foundations of European Community Law (Oxford: Clarendon Press, 3rd edn., 1994); D. Wyatt and A. Dashwood, European Community Law (Oxford: Clarendon Press, 3rd edn.); S. Weatherill and P. Beaumont, EC Law (London: Penguin Books, 2nd edn., 1995); J. Steiner, Textbook on EC Law (London: Blackstone Press, 4th edn., 1994); A.H. Robertson, The Council of Europe: Its Structure, Functions and Achievements (London: Stevens, 1956); J.G. Merrills, Human Rights in Europe: A Study of the European Convention on Human Rights (Manchester: Manchester University Press, 4th edn., 2001); A. Bloed (ed.), The Conference on Security and Cooperation in Europe: Basic Documents 1993 - 1995 (The Hague: Martinus Nijhoff, Publishers, 1997); J. Maresca, To Helsinki-The Conference on Security and Co-operation in Europe 1973-75 (Durham, N.C.: Duke University Press, 1985); A. Bloed and P. Van Dijk, Essays on Human Rights in the Helsinki Process (Dordrecht: Martinus Nijhoff, Publishers, 1985); A. Bloed and P. Van Dijk, The Human Dimension of the Helsinki Process (Dordrecht: Maritinus Nihjoff, Publishers, 1991); all cited in Rehman, n. 2, at 1-2.

117 Rehman, n. 2.

118 Ibid., at 2-3.
} 
In the words of Rehman, "the new States that emerged, in common with those that had not been directly colonized, such as Afghanistan and Nepal, have had a tumultuous relationship with constitutional development, economic growth, democracy and human rights." 119 Afghanistan's political and constitutional history has been one of conflict and civil war. The repression and human rights violations characterizing the ten-year rule of the Taliban were a consequence of the support given to fundamentalist groups, who married opposition to the Soviet occupation with extremist ideology. Notwithstanding the replacement of the Taliban regime with a new government Afghanistan "remains a constitutional quagmire". Large-scale and systematic human rights violations continue, committed by local and regional warlords who, according to Human Rights Watch, "now represent the primary threat to peace and security in the country". ${ }^{120}$ Afghanistan has a tense relationship with Pakistan, which has itself experienced military rule, lack of democracy and human rights violations for much of its independent history. However, the principal source of tension in the region lies in the conflict between its two nuclear powers, Pakistan and India, particularly in the territorial dispute over the predominantly Muslim province of Jammu and Kashmir, and in mutual allegations of state-sponsored terrorism and human rights abuses. ${ }^{121}$ Though a constitutional democracy, India has undergone periods of crisis where constitutional and political development has been badly affected by domestic terrorism (such as the assassination of two Prime Ministers, Indira Gandhi and her son Rajiv Gandhi), the declaration of a State of Emergency in 1975, regular outbreaks of communal violence, dissension over the rights of Adivasis or tribals, Dalits, minority rights, and the recognition of regional languages.

\subsubsection{SAARC: its role and remit}

As can be seen from the experience of the Council of Europe, the European Union, the African Union (formerly the Organisation of African Unity) and the InterAmerican System of Human Rights, regional institutions can play a significant role in developing norms of democratic governance, constitutionalism, the rule of law, and human rights. Regional agencies have also traditionally been valued in dispute resolution and in attempts to eradicate terrorism. ${ }^{122}$ The pre-eminent regional organization for South Asia is the South Asian Association for Regional Cooperation,

119 Ibid., at 3. See also C. Baxter, Y.K. Malik, C.H. Kennedy, and R.C. Oberst, Government and Politics in South Asia: Pakistan, India, Bangladesh and Sri Lanka, Nepal, Bhutan and the Maldives (Lahore: Vanguard), at 62; M. Hutt (ed.), Nepal in the Nineties: Versions of the Past, Visions of the Future (London: Oxford University Press, 1994); H. Skar, "Nepal, Indigenous Issues and Civil Rights: The Plight of the Rana Tharu", in R. Barnes, A. Gray and B. Kingsbury (eds.), Indigenous Peoples of Asia (Ann Arbor, MI: Association of Asian Studies, 1993), at 173-194; all cited in Rehman, n. 2, at 3.

${ }_{120}$ Rehman, n. 2, at 4.

121 Ibid., at 5.

122 See C. Gray, "Regional arrangements and the United Nations collective security system" in H. Fox (ed.), The Changing Constitution of the United Nations (London: British Institute of International and Comparative Law, 1997), at 91-116: cited in Rehman, n. 2, at 7. 
or SAARC, established in December 1985 on the basis of a document drafted by the late president of Bangladesh, President Zia-ur-Rahman, and with a current membership of Bangladesh, Bhutan, India, Maldives, Nepal, Pakistan, and Sri Lanka. ${ }^{123}$ Its remit is to promote, via the mechanism of dialogue and cooperation, regional peace and stability (including the eradication of terrorism) and the welfare of the peoples of South Asia through economic growth and development, social and cultural progress, and the promotion of mutual trust and understanding. ${ }^{124}$ It operates through a hierarchical institutional structure involving, at different levels, the participation of Heads of State, Foreign Ministers, Foreign Secretaries, civil servants, and technical experts in Summit Meetings, Council Meetings, and a variety of finance, co-ordinating and technical Committees. In addition, it has established a number of institutions and agreements designed to assist the achievement of its economic objectives. Through the framework of SAARC as an organization, Member States have, at least in principle, been able to agree on some of the fundamental principles affecting human rights and regional peace and security.

\subsubsection{The regional convention on the suppression of terrorism}

Under the auspices of SAARC a Regional Convention on the Suppression of Terrorism was adopted in 1987. Rehman observes that

"Regional terrorism has been an endemic aspect of the political relationships of SouthAsian States... [N]ot only have non-State actors conducted terrorist acts but organs of States themselves have been implicated in terrorism and gross human rights violations." $^{125}$

He goes on to note that all States of the region have been affected by domestic militancy, and by cross-border or internal opposition movements that have resorted to terrorism:

"The crime of terrorism represents the culmination of fundamental human rights violations. Whatever definition is accorded to terrorism, it violates the principal human rights as enshrined in the International Bill of Rights." 126

\footnotetext{
123 Rehman, n. 2, at 9.

${ }^{124}$ Note however that SAARC's remit does not specifically include the promotion of human rights as such; see full text of the SAARC Charter at http://www.nepaldemocracy.org/saarc_charter.html (1 September 2003).

125 Rehman, n. 2, at 12.

126 See e.g. United States Diplomatic and Consular Staff in Tehran (United States of America v. Iran), Judgment 24 May 1980, ICJ Rep. 1980, at 3, where the International Court notes: "Wrongfully to deprive human beings of their freedom and to subject them to physical constraint in conditions of hardship is in itself manifestly incompatible with ... the fundamental principles enunciated in the Universal Declaration of Human Rights", cited in Rehman, n. 2, at 15.
} 
Given that finding a definition of terrorism has proved highly controversial, the Convention adopts a broad approach towards definition. In addition, Rehman notes, Member States are given further discretion "to expand the scope of terrorist acts, by recognising other serious violent offences as terrorist acts and denying these the stature of political offences" - provisions which, whilst expanding the scope of the Convention, risk creating ambiguity and confusion, given the varying nature and scope of criminal offences in the different legal systems. ${ }^{127}$ The Convention is also mindful of the principles of cooperation of the SAARC Charter as well as of the seriousness of the problem of terrorism that has dogged the region. Thus, while re-affirming the principles of international law, the Preamble acknowledges that "cooperation among SAARC states is vital if terrorism is to be prevented and eliminated from the region".

\subsubsection{Assessment}

Since its creation SAARC has provided a valuable forum for regional inter-state dialogue at the highest level. However, despite notable achievements such as the adoption of the Regional Convention on the Suppression of Terrorism, Rehman describes SAARC as remaining "a minor player in generating the spirit of constitutionalism, democracy and human rights." 128 Crucially, SAARC's effectiveness is significantly reduced by its lack of legislative and enforcement powers. A more prominent role for SAARC, including the greater visibility and extension of its existing activities in the fields of human rights and democracy, would require an increase in its legislative and enforcement powers. Such a development would depend in particular on the willingness of its Member States to accord it greater legislative power.

\subsection{A sub-regional human rights system for South Asia?}

Asia is today the only region in the world without a regional human rights system. The need for States in those areas in which regional human rights arrangements do not already exist to consider the establishment of regional and sub-regional arrangements for the promotion and protection of human rights was emphasized in the 1993 Vienna Declaration and Programme of Action ${ }^{129}$ and has subsequently been reiterated in a succession of UN Human Rights Commission and General Assembly resolutions on regional arrangements for the promotion and protection of human rights. ${ }^{130}$

\footnotetext{
${ }^{127}$ Rehman, n. 2, at 14.

128 Ibid., at 17.

129 See n. 7, Article 37.

130 For example General Assembly Resolutions of 7 March 1995: A/RES/49/189; 3 March 1997: A/RES/51/102; 10 March 1999: A/ RES/53/148; 14 March 2001: A/RES/ 55/105.
} 
In addition to SAARC there are a number of other fora for regional human rights cooperation in South Asia. Three of these, the Asia Pacific Forum for National Human Rights Institutions, the UN Asia Pacific Workshops on Cooperation for the Promotion and Protection of Human Rights, and the South Asia Forum for Human Rights will be considered briefly. The Asia Pacific Forum for National Human Rights Institutions was established in 1996 following the first Asia Pacific regional meeting of national human rights institutions convened by the United Nations Office of the High Commissioner for Human Rights. ${ }^{131}$ The Forum consists of national human rights institutions that conform to the standards set out in the 1993 UN General Assembly "Paris Principles" relating to the status of national human rights institutions. ${ }^{132}$ The bulk of the Forum's twelve member institutions are from East Asian, South East Asian and Pacific Rim states; South Asia is poorly represented, the only member institutions being the National Human Rights Commissions of India, Nepal and Sri Lanka. The object of the Asia Pacific Forum is to protect and promote the human rights of the people of the Asia Pacific region ${ }^{133}$ by supporting, through regional cooperation, the establishment and development of independent national human rights institutions, and by promoting cross-sector cooperation and joint activity on human rights. As an organization for regional dialogue and cooperation rather than an embryonic regional human rights system, the Forum has no judicial or quasi-judicial function or powers. Its activities at regional level include specialist training programmes and thematic regional workshops for member institutions, with annual meetings intended to serve as a mechanism for the practical advancement of human rights in the region. At international level, representatives of the Forum's member institutions together with NGO (non-governmental organization) representatives participate as observers in the intergovernmental Asia Pacific Workshops on Cooperation for the Promotion and Protection of Human Rights in the Asia Pacific region, convened regularly by the United Nations since 1982. ${ }^{134}$ Through these UN Workshops a regional consensus has been reached on what is described as a "step by step" "building-blocks" approach, involving extensive government consultation, concerning the establishment of regional human rights arrangements in Asia. The Framework for Regional Technical Cooperation adopted at the 1998 Regional Workshop in Tehran (the "Tehran Framework") confirmed the "step by step" process towards establishing regional

\footnotetext{
131 The Asia Pacific Forum of National Human Rights Institutions was established under Australian law as a non-profit company limited by guarantee. It is funded primarily by the UN Office of the High Commissioner for Human Rights and the governments of Australia and New Zealand.

132 A/ RES/48/134 of 20 December 1993.

133 Article 2 of the Constitution of the Asia Pacific Forum of National Human Rights Institutions, adopted at the sixth annual meeting of the Forum in Colombo, Sri Lanka in September 2001.

134 The UN Regional Workshops bring together senior government representatives from governments in the Asia Pacific region with responsibility for human rights issues, with national human rights institutions and NGOs participating as observers.
} 
human rights arrangements ${ }^{135}$ and identified four key areas for regional cooperation in human rights. ${ }^{136}$

The South Asia Forum for Human Rights (SAFHR), established in 1993, is a regional public forum for the promotion of universal standards of human rights. It aims, through mechanisms such as people-to-people dialogue and the development of regional communications networks, to expose human rights abuses in the region, to provide a forum for the exchange of ideas on human rights, and through education and study programmes to raise awareness of human rights issues and the links between human rights, peace and democracy. ${ }^{137}$

Existing regional human rights systems vary considerably. Typically, though, they comprise a regional instrument backed up by monitoring and enforcement mechanisms in the form of a Commission or similar body and a Court. South East Asian and East Asian NGOs have already drawn up two regional human rights instruments, the Declaration on Basic Rights and Duties of ASEAN Peoples and Governments, ${ }^{138}$ and the Asian Human Rights Charter. ${ }^{139}$ A similar exercise could be undertaken by South Asian NGOs with a view to producing a sub-regional instrument for South Asia as a basis for tripartite discussions between governments, NGOs and national institutions in the South Asia region. ${ }^{140}$ SAFHR has already highlighted the need for South Asian states to develop and adopt a regional charter or protocol for the protection of refugees and displaced persons. The combined expertise of the Asia Pacific Forum's member institutions, its government and NGO participants, together with those parties involved in the UN Asia Pacific Regional Workshops, SARRC and SAFHR, must be combined to chart the way forward for the creation of a sub-regional human rights system in South Asia, which should be accorded from

\footnotetext{
135 Sixth Workshop on Regional Arrangements for the Promotion and Protection of Human Rights in the Asian and Pacific Region (28 Feb - 2 March 1998): Tehran Workshop Conclusions. UN Doc. E/CN.4/1998/50 Annex I.

${ }^{136}$ Development of national plans of action for the promotion and protection of human rights and the strengthening of national capacities; human rights education; development of national institutions for the promotion and protection of human rights; development of strategies for the realization of the right to development and economic, social and cultural rights.

137 Mission Statement of South Asia Forum for Human Rights (SAFHR) adopted by the founding body of SAFHR on 19 February 1993 at Kathmandu, Nepal.

138 Declaration adopted by the First General Assembly of the Regional Council on Human Rights in Asia on 9 December 1983, in Jakarta, Indonesia and presented to the ASEAN Secretariat on the same day.

139 Charter drafted by the Asian Human Rights Commission, Hong Kong and formally declared on 17 May 1998 in Kwangju, South Korea.

140 The notion of a specifically Asian approach to human rights which emphasises the particularities of the Asia-Pacific region, highlighted in the 1993 Report of the Regional Meeting for Asia of the World Conference on Human Rights and challenged by the 1993 Bangkok NGO Declaration for its downplaying of civil and political rights at the expense of economic, social and cultural rights (the so-called "Asian values" debate), is particularly associated with the viewpoint of South East and East Asian states.
} 
the outset adequate legislative and enforcement powers along the lines of the European regional human rights system. ${ }^{141}$

\section{CONCLUSION}

As the papers summarized in this article show, South Asia's record to date on the promotion and effective protection of human rights and fundamental freedoms is poor, but the potential for change exists if national governments are willing to accept the challenge. At the international level, the ratification of universal human rights instruments by all States in the region must be achieved, ideally without resort to reservations. At the national level, States are failing in their duty to eliminate all violations of human rights and their causes, and obstacles to the enjoyment of these rights. The consequence of this failure is incalculable human misery across the region. The development and strengthening of independent national justice systems and law enforcement agencies is a prerequisite to the provision of effective remedies for human rights violations. States must work towards the creation of a human rights culture in all aspects of society through education on human rights, democracy and the rule of law. At the regional level, channels for inter-governmental dialogue and for dialogue between governments, national institutions and NGOs already exist. This dialogue must be deepened and developed with a view to drafting and adopting a regional human rights system for South Asia - one that must be accorded adequate legislative and enforcement powers. There can be no advancement of human rights in the region in the absence of genuine political commitment on the part of States. If South Asian States are to tackle the human rights crisis confronting the region, as analyzed in this overview, they must be willing to take the steps indicated above.

141 Established in 1951 by the Council of Europe; see Rehman, n. 16, at Chap. 6. 